\title{
The Path between Personality, Self-Efficacy, and Shopping Regarding Games Apps
}

\section{Sonia San-Martín', Nadia Jimenez'1, Carmen Camarero², Rebeca San-José2}

${ }^{1}$ Universidad de Burgos, Departamento de Economía y Administración de Empresas, Burgos, Spain, sanmargu@ubu.es,nhjimenez@ubu.es

2 Universidad de Valladolid, Departamento de Organización de Empresas y Comercialización e Investigación de Mercados, Valladolid, Spain, camarero@eco.uva.es, rebecasc@eco.uva.es

Received 13 August 2018; received in revised form 26 May 2019; accepted 2 June 2019

\begin{abstract}
The smartphone has made gaming more accessible and desirable for a wider market than ever before. Game apps are one of the most consumed and fastest growing products in the world today. Yet, few studies have thus far explored the implications of games apps consumption from a consumer perspective, addressing the transfer of abilities from one technological field to another. The main purpose of this paper is threefold: to ascertain the role of personality as a determinant of self-efficacy, to establish whether there is a transfer process from selfefficacy in video gaming with apps to online shopping and to analyze the impact of self-efficacy on the online purchase of game-related products. Results show that neuroticism, extraversion, and agreeableness determine the gaming self-efficacy that is transferred to online shopping self-efficacy and finally to the online purchase of game-related products. These insights provide interesting managerial implications that could affect video game marketing.
\end{abstract}

Keywords: Game apps, Self-efficacy, Personality, Shopping, Big five 


\section{Introduction}

The video game industry has become a major contributor to the global entertainment economy, moving quickly into digital contexts. Yet research on the issue remains limited [65], [51]. Indeed, the video game is a product that generates an important volume of business worldwide. For several years now, the video game industry has been generating more economic activity than other cultural and creative industries (such as, performing arts market, architectural market, design industry, broadcasting industry, book market, press market, art market, film industry, advertising market or music industry) and continues to grow exponentially due to its widespread acceptance [41], [72], [74]. Specifically, there are more than 2.4 billion gamers worldwide, and the value of the global gaming (throughout the paper, gaming refers to playing video games) market stands at 231.6 billion dollars [71]. The mobile game market represents $47 \%$ of the game industry's total sales, surpassing the console $(28 \%)$ and the computer $(25 \%)$ [71]. Due to the massive increase in personal digital distribution, the scope of video games is much greater than in the case of offline distribution. One key factor influencing the growth of the video game industry is increased smartphone penetration (2.5 billion smartphone users worldwide) [87], which has brought this product to a wider audience and even represents an alternative new business model [65], [98], leaving video game consoles for users who spend more time playing [39], [71].

Regarding the up-to-date top mobile game app information, the global mobile gaming app revenue will represent 74.6 billion U.S. dollars in 2020 [89]. The preferred format for European gamers is the free and freemium game (55\% of video gamers have tried between two and five new games in 3 months) [40]. The freemium model (free download game but premium -money- is charged for additional features) now dominates the ecosystem of mobile games, provides $95 \%$ of its revenues and it is mainly subsidized by advertisements [40]. Each day 2500 and 236 game apps are published on the two main global platforms (Google Play and Apple App Store, respectively) but a freemium game -Clash of Clans- is the leading mobile game title worldwide (with revenue of 1.35 billion U.S. dollars) [88], [89]. However, the games that show the higher increase are eSports (26\%) and virtual reality ones (259\%) [39].

Every day, smartphones are being used for a growing number of activities: we phone, we chat, we browse, we read, we play, and we buy. The device's use has increased individuals' abilities and their confidence to use it for additional tasks and functions. Therefore, it may be conjectured that the abilities acquired when playing game apps with the smartphone (or tablet) may be transferred to other uses of the smartphone (or tablet), specifically, to online purchasing of game-related products. Both activities are performed through new technologies, an electronic device and a screen, and require direct interaction with users, which has a direct impact on them and their environment [22]. We can assume that the abilities and skills acquired by individuals when playing with game apps prepare them to deal with online purchase platforms such that they might perceive online shopping as easy as online playing.

These facts and issues pose some questions concerning the video game area. Is gaming behavior related to online shopping behavior? Might there be a transfer of relevant variables, such as self-efficacy, from one field of technology use (video gaming) to another (online shopping)? Does personality exert any influence on self-efficacy and such a transfer process? Bearing these questions in mind, this research pursues three goals: a) to establish whether gamer personality determines self-efficacy; b) to ascertain whether there is a transfer process between self-efficacy in video gaming and online shopping, and c) to analyze the impact of self-efficacy on the online purchase of game-related products.

As for the first objective, based on the trait-theory, we focus on personality traits (extraversion, agreeableness, conscientiousness, neuroticism, and openness) as psychological factors related to the skills and abilities that use technologies either to play or to buy. Researchers have highlighted that personality is a major issue in studying human dynamics on line [56]. It is a key to brand success for [62], a key in online gambling behaviour [1], a key in the use of social networks [20] and, for [38], [97], a key in which video game to play.

As regards the second objective, and despite it being somewhat evident, the relationship between playing video games and using electronic commerce has rarely been explored. Specifically, this study deals with two prominent digital media forms in today's social environment - playing game apps and online shopping- [58]. According to the self-efficacy theory, one key factor to successfully perform both tasks is self-efficacy, that is, one's belief in one's ability to succeed in specific situations or to accomplish a task [13]. Game playing, and online shopping require a certain level of expertise, knowledge, or skills if they are to be executed successfully.

Finally, regarding the third objective and although other authors have already studied self-efficacy as a determinant of technology adoption and purchase behaviour [43], [45], [52], [91], our innovative model applied to video gaming proposes a sequence from personality to self-efficacy and to the online purchase of game-related products. By studying personality traits and self-efficacy, this work presents a more humanistic viewpoint in the analysis of consumer behavior and the adoption of new technologies and provides a distinctive approach from the more techno-centric models (i.e., the Technology Acceptance Model), as [82] also emphasize. Moreover, the possibility that there might be transferable skills between different technologies that can lead to self-efficacy with one technology being transferred to another field of technology use is yet to be addressed in the literature. 
Apart from seeking to address the above-mentioned gaps in the literature and making the mentioned academic contributions, the empirical analysis has been carried out on a wide sample of actual Spanish app gamers. According to [39], Spain is one of the strongest markets in the sector. Specifically, the Spanish market ranks ninth in the world and fourth in Europe behind China, USA, Japan, Germany, United Kingdom, Korea, France and Canada. In Spain, there are over 450 video game companies, most of them created recently (52\% are less than five years old), and the last reported turnover amounted to 617 million euros (being expected to rise to 1440 million euros in 2020) [39]. According to [75], 28.7\% of Spanish online shoppers claim to be fond of video games (playing and downloading), which is $7.5 \%$ bought them online and spent at least $72.9 €$ at year. Of these, $69.9 \%$ play video games through smartphones and, to a lesser extent, through the computer (38.3\%). Online consumption of video games amounted to 474 million euros, and 223 million euros come from game apps [3].

In the second section, the theoretical framework of the study is presented and, the proposed model and the hypotheses are discussed. In the third section, the methodology and results are shown. The section four, includes the discussion as well as the limitations and future research. The last section, section fifth, includes the conclusion.

\section{Conceptual and Theoretical Background and Proposed Hypotheses}

In this section, the key role of consumer personality and self-efficacy is highlighted. First, the Big Five model is used as a theoretical framework to understand video gamer personality. Second, the theory of self-efficacy is revised to understand this variable and how it derives from the five personality traits. Finally, a transference process from gaming self-efficacy to online shopping self-efficacy and purchase intention is proposed.

\subsection{Consumer Personality. Big Five}

The Trait Theory is the most influential school of thought in personality psychology [62]. Specifically, one of the most well-known and widely used personality models in psychology to measure the five previously mentioned personality traits is the Big Five model [20], [32], [60], [62], [81], [82]. Indeed, behaviors are better predicted using a common framework such as the Big Five [83]. Recently evidence [73] reveals that personality traits could be reliable sources to describe consumers' behaviors.

Following [32], [38], [62], [67], [82], personality traits are the extent to which consumers appraise themselves regarding five dimensions: (1) conscientiousness assesses one's degree of organization, persistence, and motivation in goaldirected behaviour; (2) neuroticism assesses an individual prone to psychological distress, unrealistic ideas, excessive cravings or urges, and maladaptive coping responses; (3) extraversion assesses an individual's quantity and intensity of interpersonal interaction and activity level; (4) agreeableness assesses an individual's quality of interpersonal orientation along a continuum from compassion to antagonism in thoughts, feelings, and actions; and (5) openness assesses an individual's proactive seeking and appreciation of experience for its sake, toleration for, and exploration of the unfamiliar.

In the context of video games and online games, personality traits have been related to the fact of playing or not, the style of playing, addiction to video games, and the motivations and benefits derived from playing (see Table 1). However, the link between the Big Five traits and self-efficacy playing has yet to be studied.

Table 1: Research on video gamers and Big Five personality traits

\begin{tabular}{|l|l|l|l|l|}
\hline Subject & Source & Dependent variable & $\begin{array}{l}\text { Significant } \\
\text { personality traits }\end{array}$ & Study context \\
\hline \multirow{2}{*}{$\begin{array}{l}\text { Playing } \\
\text { (frequency, } \\
\text { style) }\end{array}$} & {$[90]$} & Online playing & $\begin{array}{l}\text { Extraversion (+) } \\
\text { Conscientiousness } \\
(+) \\
\text { Openness }(+)\end{array}$ & $\begin{array}{l}\text { 130 pairs of students } \\
\text { (players and non- } \\
\text { players) }\end{array}$ \\
\cline { 2 - 5 } & {$[16]$} & $\begin{array}{l}\text { Playing style } \\
\text { (Player versus player; } \\
\text { Player versus } \\
\text { environment; } \\
\text { Role player) }\end{array}$ & $\begin{array}{l}\text { Extraversion } \\
\text { Conscientiousness } \\
\text { Neuroticism } \\
\text { Openness }\end{array}$ & $\begin{array}{l}1,349 \text { World of } \\
\text { Warcraft players }\end{array}$ \\
\cline { 2 - 5 } & {$[85]$} & Mobile game playing & $\begin{array}{l}\text { Agreeableness (-) } \\
\text { Openness }(+)\end{array}$ & $\begin{array}{l}1,995 \text { mobile game } \\
\text { players }\end{array}$ \\
\hline
\end{tabular}




\begin{tabular}{|c|c|c|c|c|}
\hline \multicolumn{5}{|c|}{ Table 1: continuation } \\
\hline \multirow{4}{*}{$\begin{array}{l}\text { Problematic } \\
\text { playing }\end{array}$} & [31] & $\begin{array}{l}\text { Problematic video } \\
\text { game playing }\end{array}$ & Agreeableness (-) & $\begin{array}{l}225 \text { participants (66 } \\
\text { players of } \\
\text { MMORPGs) }\end{array}$ \\
\hline & [6] & $\begin{array}{l}\text { Addiction to video } \\
\text { games }\end{array}$ & Conscientiousness (-) & $\begin{array}{l}218 \text { undergraduate } \\
\text { students }\end{array}$ \\
\hline & [96] & $\begin{array}{l}\text { Addiction to video } \\
\text { games }\end{array}$ & $\begin{array}{l}\text { Conscientiousness (-) } \\
\text { Neuroticism (+) }\end{array}$ & 3,389 video gamers \\
\hline & [23] & $\begin{array}{l}\text { Internet gaming } \\
\text { disorder }\end{array}$ & $\begin{array}{l}\text { Extraversion (-) } \\
\text { Conscientiousness (-) } \\
\text { Neuroticism (+) } \\
\text { Openness (-) }\end{array}$ & 2,891 online players \\
\hline \multirow{3}{*}{$\begin{array}{l}\text { Motivations } \\
\text { and benefits }\end{array}$} & [76] & $\begin{array}{l}\text { Motivation to play } \\
\text { online games } \\
\text { (Relationships, } \\
\text { Adventure, Escapism, } \\
\text { Relaxation, } \\
\text { Achievement) }\end{array}$ & $\begin{array}{l}\text { Extraversion (+) } \\
\text { Agreeableness (+) }\end{array}$ & $\begin{array}{l}524 \text { players and non- } \\
\text { players }\end{array}$ \\
\hline & [49] & $\begin{array}{l}\text { Motivation to play } \\
\text { MMORPGs } \\
\text { (Social, Achievement, } \\
\text { Immersive, Leadership, } \\
\text { Independence) }\end{array}$ & $\begin{array}{l}\text { Extraversion } \\
\text { Agreeableness } \\
\text { Conscientiousness } \\
\text { Neuroticism } \\
\text { Openness }\end{array}$ & $\begin{array}{l}1,413 \text { World of } \\
\text { Warcraft players }\end{array}$ \\
\hline & [30] & Life satisfaction & $\begin{array}{l}\text { Conscientiousness } \\
(+) \\
\text { Neuroticism }(+) \\
\text { Openness }(+)\end{array}$ & 500 online players \\
\hline
\end{tabular}

\subsection{Self-Efficacy Role}

The theory of self-efficacy lies at the heart of Bandura's Social Cognitive Theory [10]. Self-efficacy refers to peoples' judgment of their ability to organize and execute courses of action required to attain designated types of performance [12], [35]. It is domain specific and strongly tied to the behavior of interest. Self-efficacy is concerned not only with the skills one has but also with the confidence with which one uses those skills [14], [35], [91].

As with self-confidence or self-control [64], self-efficacy is an individual resource, according to psychology literature. However, unlike other self-traits such as self-esteem, self-efficacy refers to individuals' self-assessment of their capacity to accomplish a given task and achieve a particular goal [13], [58]. Self-efficacy is a broader engagement of inner resources that encompasses feelings, cognitions, and behaviors [91].

On this conceptual basis, we can identify different self-efficacy domains. In fact, self-efficacy has been studied in different fields of knowledge, such as student learning [59], [101], employee behaviour [17], [84], [99], consumer reactions [20], [77], [91] and video gaming [57]. Different technologies have also been addressed in self-efficacy literature: computer self-efficacy [43], [82] or Internet self-efficacy [43], [45], [52], [61]. However, research has seldom studied self-efficacy applied to the video game industry [57] or online shopping [43].

In this work, we consider gaming self-efficacy as individuals' self-assessment of their capacity to solve the challenges posed in a game and to become skilled in a game app. In the context of video games, we have only found the study by [57], which specifically uses video gaming self-efficacy and computer gaming self-efficacy. Similarly, online shopping self-efficacy refers to individuals' self-confidence when searching for and acquiring products and services in online stores [36]. Following several authors, self-efficacy is specifically related to different contexts and concepts, giving rise to various kinds of self-efficacy apart from general self-efficacy [29], [52], [57]. As an example, [43] distinguished between general Internet self-efficacy and specific www self-efficacy as different concepts.

The predictive capability of self-efficacy is strongest and most accurate when determined by specific domain-linked measures rather than by general measures [82]. In this line, specific self-efficacy is one of the factors that proves a key driver vis-à-vis understanding individual behavior and adoption of new technologies [43], [45], [52], [61], [82]. For instance, [64] emphasize the importance of possessing expertise and self-control in order to perform shopping tasks successfully. While players who value video game success as part of their identity may reap benefits from video game playing, those who do not value such success may experience more harmful effects [92]. 


\subsection{Personality-Self-Efficacy Link}

High self-efficacy is attributed to individuals' beliefs that they can manage and solve the problems at hand more successfully [91]. However, self-efficacy can be influenced by personality. Individuals' personality can affect their level of self-efficacy [13]. Nevertheless, few studies have related personality traits with consumer self-efficacy [52], [58], [61], [77], [91]. Some studies have explored personality traits as drivers of gamer behavior [23], [30], [49], [85], although to the best of our knowledge, none have thus far related personality to self-efficacy in a video gaming context.

As regards conscientiousness, [77], [82] found that it is positively associated with task fulfillment and job performance and that it influences self-efficacy. In the context of gaming, it can be assumed that game players must be persistent if they are to achieve game goals and be successful. In other words, persistence and motivation allow players to achieve self-efficacy and become skilled players.

As for neuroticism, [82] find that neuroticism negatively influences self-efficacy. Individuals' psychological distress may limit their ability to become skilled and thus obtain the expected achievements in a game. Indeed, one of the harmful effects of playing video games is stress and anxiety [69].

As for extraversion, in gamer behavior [26] argue that social influence, which explains how other people's attitudes or opinions may affect an individual's decision making, is a determining factor in social games. Extraversion positively influences self-efficacy [82]. Interacting with other people, coupled with a tendency to be sociable, may increase their knowledge of the game and their abilities and skills when playing it, as suggested by [100].

Results concerning the effects of agreeableness on self-efficacy are mixed. While [62] finds a significant relationship between agreeableness and brand loyalty in the case of video games, [60] observe a negative effect of agreeableness and Internet usage, and [82] find that agreeableness negatively influences self-efficacy. These authors argue that there is no reason to propose a positive relationship between agreeableness and self-efficacy since the former is related to higher computer anxiety and less use of mobile phones. In [55], agreeableness was not significantly related to selfefficacy.

Finally, individuals displaying openness are more willing to try something new and also possess good imagination. An open mind is usually an advantage when solving problems at work and in life; consequently, open-minded individuals would also have a positive evaluation of their efficacy [77]. Openness increases loyalty to video games [62] and, in the same line, [66] show that openness relates to brand loyalty to products which have a hedonic value. Also, [82] find a positive influence of openness on self-efficacy. In the context of gaming, players' openness involves searching for new experiences as well as imaginative and innovative games. Eventually, the search for new experiences might increase their abilities in the game.

Gamers are thus expected to display greater self-efficacy if they are organized and persistent (conscientious); not worried, nervous and emotionally stable (not neurotic); sociable, optimistic and talkative (extrovert); unforgiving, cold and skeptical (not agreeable) and curious, creative and imaginative (open). Following the previous reasoning, the hypotheses proposed reflect the effect of personality traits on gaming self-efficacy.

\section{H1: Conscientiousness positively influences gaming self-efficacy.}

H2: Neuroticism negatively influences gaming self-efficacy.

H3: Extraversion positively influences gaming self-efficacy.

H4: Agreeableness negatively influences gaming self-efficacy.

H5: Openness positively influences gaming self-efficacy.

\subsection{Proposed Transfer between Gaming Self-Efficacy and Online Shopping Self-Efficacy}

As [45] affirms, Internet has potentially and irrevocably impacted on the way business is conducted and has redefined the parameters of business in general. Indeed, the Internet has grown to become one of the leading sales channels today, with game apps being no exception [65]. Prior research provides evidence about the link between mobile gaming and online shopping behavior [11]. [93]'s study has found that richer online formats and recommendations throughout video games enhance consumers' perceptions about experience products and positively affect consumers' intentions to purchase products. Furthermore, [44] found that app-based gaming has created complex models to generate purchase (in and out the game). Models that comprises explicit exchange of money for digital items within each game or economic systems based on virtual assets (e.g., Worldwide Asset eXchange and OPSkins market) and no explicit -nor direct- purchase related to the game (i.e., through branding freemium games or ads). Recent data [34], [89] suggest that video gamers conduct in-game purchases, such as upgrades, additional lives, currency, personalized avatars, an ad-free experience, unrestricted playing time or special items (i.e., famous football players' avatars or skins 
that modifies the appearance of a character or item), and consumer spending on in-game purchases will grow until 32 billion in 2020. In fact, $4 \%$ of global iOS device users and $3 \%$ of Android users are making in-game purchases per month and [89].

In this context, online shoppers must demonstrate adequate self-efficacy as a precedent of Internet shopping and when buying game-related products. As [52] point out, Internet self-efficacy is not as important in offline contexts as in online contexts because consumers learn how to make an offline purchase at an early stage. In fact, consumers exhibiting low self-efficacy are uncertain and feel uncomfortable with Internet shopping [45]. Internet or computer selfefficacy is felt to be one of the best predictors of online shopping [43], [59].

To the best of our knowledge, the only study to specifically use self-efficacy during online shopping (online shopping self-efficacy as a concept) is [36]. Online shopping self-efficacy, or the belief in one's ability to organize and perform the Internet actions required to produce given attainments, is a potentially important factor when buying online.

Following Rogers' Theory of Innovation Diffusion, people are more likely to adopt an innovation they are comfortable with and that is compatible with other technologies they already use [79]. Following [13], [52], perceived self-efficacy will tend to transfer across two tasks within the same domain based on the degree of similarity between the qualitative features of the two tasks and the skill they require. Recently, [100] found evidence of transfer of technological game knowledge between different individuals interacting in the same group.

As [43] suggests, when users decide to adopt one activity they tend to adopt another similar one. According to his study, people are more likely to adopt information technologies that are functionally compatible with those previously adopted. More specifically, [43] proposes that prior use of the telephone is positively related to adopting online shopping and that Internet self-efficacy has a positive relationship with the adoption of online shopping. Following his arguments, and applying them to our research context, when playing with game apps and when purchasing online game-related products, when users complete transactions over the Internet they must transfer private information over the network creating a similar mode of action between the two contexts. Moreover, gaming and online shopping require a similar amount of skill and are contingent on the same premise (fulfilling users' goals successfully and facing the challenge of winning the game or receiving high-quality game-related products). These arguments are coherent with what [79] calls technological clustering, which occurs when adopters of a given innovation perceive another new idea as being closely related. Therefore, when consumers exhibit self-efficacy playing a video game, they will probably display this ability when purchasing related products. Therefore, we propose that video gamers acquire several skills when playing, the fact that allow them to feel more self-confident and effective when using online shopping platforms to buy games or accessories.

This self-efficacy transfer argument also fits in with the evidence regarding the benefits of video games as teaching tools [25], [100]: they are used for military training, for teaching in schools, or for teaching perceptual skills (such as attending to more visual cues). "By playing video games the individuals learn scripts, organized sets of knowledge that define situations and guide behaviors" [25] (p. 368) and how to solve problems. They conclude that video games can teach, regardless of their content and regardless of the gamer's intended use.

Thus, the following hypothesis tests self-efficacy transfer from one technological field (video gaming) to another (online shopping). Summing up, this hypothesis contains a novel contribution to the literature in this study and involves personality traits determining gamer self-efficacy and these skills being transmitted to other activities, specifically to online shopping.

\section{H6: Gaming self-efficacy positively influences the self-efficacy of online purchases of game-related products.}

\subsection{The Influence of Self-Efficacy on the Intention to Purchase Online}

One of the main goals pursued by most companies is to attract and retain customers, which is also applicable to online game-related shopping. Purchase intention is defined as the players' willingness to purchase virtual items for use in the mobile game [8]. Players may need to buy additional complements and items if they want to progress quickly in the game (extra time, lives, moves, virtual items to access higher levels, etc.). In this sense, one way to achieve such a goal is self-efficacy. In fact, some authors have emphasized the importance of self-efficacy in behavior and adoption [29], [36], [82]. Internet and computer self-efficacy are two of the best predictors of online shopping [52], [59], [91]. [43] posits that self-efficacy influences overall adoption of electronic shopping. Consumers engaged in Internet shopping transactions should demonstrate adequate self-efficacy which precedes perceptions strongly associated with Internet shopping [45]. In line with these findings and suggestions, the final hypothesis reflects the idea that if gamers display self-efficacy when purchasing online game-related products, they will later acquire more games and accessories online.

H7: Online shopping self-efficacy positively influences the intention to purchase game-related products online.

Figure 1 reflects the proposed structural equation model (SEM). 


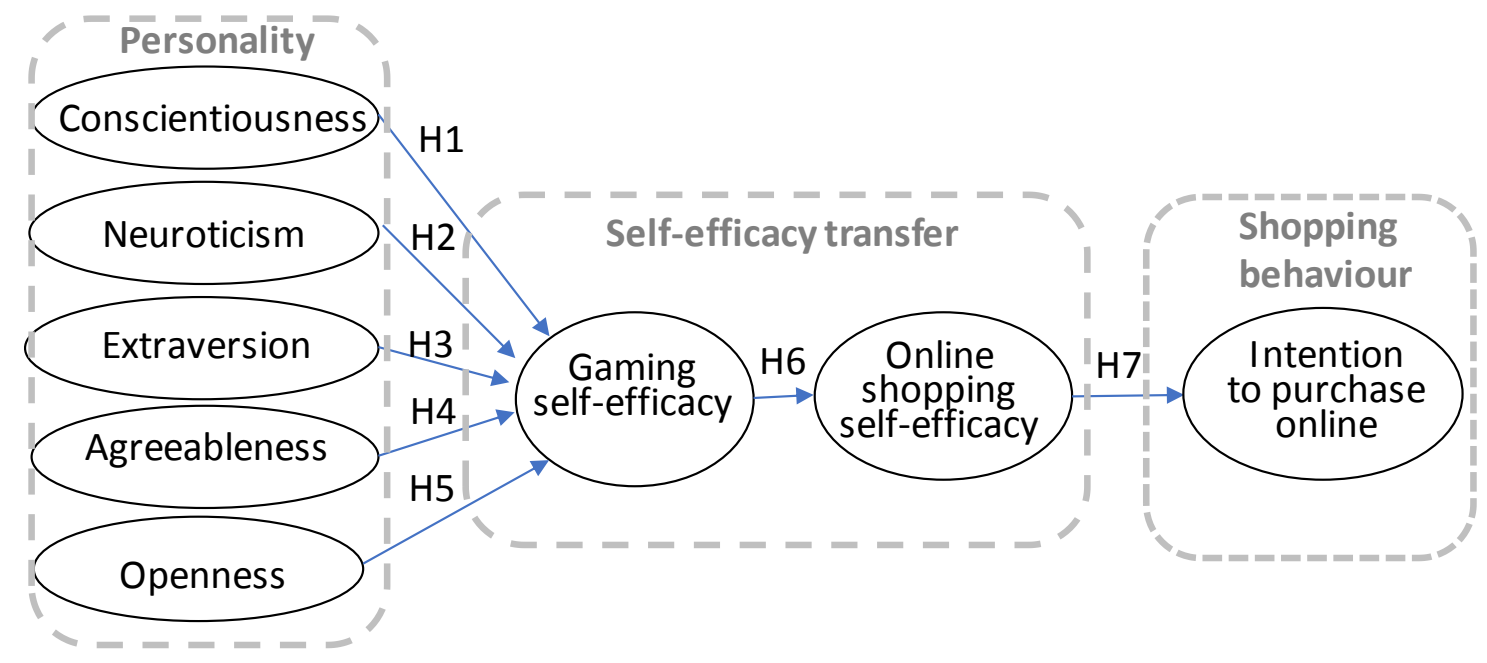

Figure 1: Proposed model

\section{Empirical Study}

In this section, the sampling process and measurement scales are described. Besides, the analyses made, the results obtained and the supported hypotheses are explained.

\subsection{Sampling and Measures}

Information was collected from a sample of 366 Spanish game app players. The questionnaire was handed out personally to players of video games who have bought online video game related products/services (e.g., extras, premium game versions, music or games), and regarding the last app game played. On average 4.5 gamers in the sample play the same game. To collect data, we used snowball sampling. We contacted a group of players each of whom was asked to answer a questionnaire and to collect two additional questionnaires from other players they knew. Participants ranged in age from 18 to $65(M=23, S D=7.81)$ and dedicated an average of 4.4 hours per week to playing game apps. The sample shows certain similarities with the average Spanish video game player. $65 \%$ is young (between 15 and 24 years old) and play an average of 6.6 hours per week [3]. Last available data from the gaming study show that $57.6 \%$ of females prefer to play with mobile game apps while $61.1 \%$ of males prefer consoles [4]. Gamer categories in Spain [54] include 56\% of males, 21\% between 6 and 24 years old; 35\% of males between 25and 64 -years old play with games apps; $44 \%$ of females are gamers, $19 \%$ aged between 6 and 24 years old and $25 \%$ of females aged between 25 and 64 years old play game apps. Table 2 provides further details about the sample profile.

Table 2: Sample characteristics

\begin{tabular}{|l|l|l|}
\hline Gender & Male & $38.9 \%$ \\
\hline \multirow{3}{*}{ Age } & Female & $61.1 \%$ \\
\hline & $18-24$ & $83.8 \%$ \\
\cline { 2 - 3 } & $25-34$ & $8.8 \%$ \\
\cline { 2 - 3 } & $35-44$ & $2.3 \%$ \\
\cline { 2 - 3 } & $45-54$ & $3.4 \%$ \\
\cline { 2 - 3 } & $55-64$ & $1.4 \%$ \\
\cline { 2 - 3 } $\begin{array}{l}\text { Frequency of use (playing) with apps } \\
\text { (mean 3.64, SD: 1.18) }\end{array}$ & $>64$ & $.3 \%$ \\
\cline { 2 - 3 } & Above the mean & $59.7 \%$ \\
\cline { 2 - 3 } & Below the mean & $40.3 \%$ \\
\hline
\end{tabular}

Note: younger individuals ( $<18$ years old) must be discarded since it is necessary an official permission for being interviewed.

All of the items used to develop the measurement instrument were adapted to the context of the study based on the indicators proposed in the literature. The short version of the Big-Five Inventory (BIF) used here is based on the studies of [38], [67]. This scale contains all of the dimensions of the Five-Factor Model of personality [67], [68] and measures 
five orthogonal factors (Extraversion, Agreeableness, Conscientiousness, Neuroticism, and Openness), one for each personality trait [7], [42]. In [48], it is suggested to include all the dimensions, since most individual differences in human personality can be classified into these five broad personality domains. The selection of specific subscales from the index to fit the research purpose was proposed by [7], [38], [47]. They have been effectively operationalized as reflective scales in recent studies on gaming and mobile purchase behavior [18], [42], [82].

Self-efficacy scales were likewise taken from prior literature so as to improve their validity content. We use the scales proposed in [13], [28], [35] to measure self-efficacy. Prior studies have tested the unidimensionality and validity of the reflective self-efficacy scale across several contexts, including mobile purchase and online behavior [82], [84]. In line with the recommendations of [21], selected self-efficacy items are the ones that best capture individual beliefs regarding specific tasks under research. To measure purchase intention, we employed a three-item reflective scale that refer to the individuals' intention to invest additional money in the game app [8] (for item details see Table 3).

The translation and reverse translation processes were completed by two native-English-speaking researchers to guarantee the readability and clarity of the survey [24], [70]. Afterward, a pilot test with 15 players was conducted to pinpoint and correct shortcomings in the questionnaire. Five-point Likert scales were used, ranging from strongly disagree (1) to strongly agree (5).

\subsection{Analysis and Results}

Data analysis was conducted using LISREL 8.7. Confirmatory factor analysis (CFA) shows that all standardized loadings are significant at .001 . After re-specification (items suppressed due to a low $\mathrm{R}^{2}$ ), results indicate that the measurement model provided a good fit to the data since all the fit indices met the threshold criteria recommended [5], [50]. Specifically, the model estimation showed a $X^{2}{ }_{(468)}$ of $837.78(p=.00)$, a Comparative Fit Index (CFI) of .93, a Goodness of Fit Index (GFI) of .90, and a Root Mean Square Error of Approximation (RMSEA) of .047. Likewise, all Cronbach alpha $(\alpha)$ values are greater than or equal to .7, except in the cases of agreeableness and extraversion, which were slightly below .7. However, since all of the remaining coefficients in our study fulfill the requirement, this might be due to the number of items comprising those constructs [47]. Furthermore, although the Cronbach alpha ( $a$ ) is the most widely used estimator of scale reliability, it is thought to underestimate reliability. A better option to test reliability is composite reliability (CR) [78]. All (CR) values exceed .7, and average variance extracted (AVE) values exceed .5 [9]. Table 3 presents elementary descriptive statistics (mean and standard deviation) for the observable variables included in the measurement model, scales validity and the significant standardized coefficients lambda $(\lambda)$ of the CFA. To test discriminant validity, the Fornell-Larcker criterion says that a factor's AVE should be higher than its squared correlations with all other factors in the model. Thus, we discard discriminant validity problems [46] (Table 4).

Table 3: Measures, descriptive statistics and scales validity

\begin{tabular}{|c|c|c|c|c|c|}
\hline Construct & Code & Items description & Mean & SD & $\lambda$ \\
\hline & \multicolumn{2}{|c|}{ I see myself as: } & & & \\
\hline \multirow{6}{*}{$\begin{array}{l}\text { Conscientiousness } \\
(\alpha=.76 ; \mathrm{CR}=.82 ; \mathrm{AVE}=.55)\end{array}$} & V1 & Careless & 3.52 & 1.21 & $.799^{\star \star}$ \\
\hline & V2 & Disorganized & 3.50 & 1.24 & $.914^{\star \star}$ \\
\hline & V3 & Undependable $^{\mathrm{a}}$ & 4.33 & 1.07 & - \\
\hline & V4 & Negligent & 3.54 & 1.17 & $.602^{\star \star}$ \\
\hline & V5 & Weak-willed $^{a}$ & 3.58 & 1.10 & - \\
\hline & V6 & Lazy & 3.28 & 1.20 & $.474^{\star \star}$ \\
\hline \multirow{6}{*}{$\begin{array}{l}\text { Neuroticism } \\
(\alpha=.77 ; \mathrm{CR}=.80 ; \mathrm{AVE}=.58)\end{array}$} & V7 & Calm & 2.99 & 1.21 & $.671^{\star \star}$ \\
\hline & V8 & At ease & 3.20 & 1.21 & $.945^{\star \star}$ \\
\hline & V9 & Secure $^{a}$ & 2.83 & 1.61 & - \\
\hline & V10 & Self-satisfied ${ }^{a}$ & 3.42 & .991 & - \\
\hline & V11 & Comfortable $^{\mathrm{a}}$ & 2.98 & 1.24 & - \\
\hline & V12 & Relaxed & 3.02 & 1.15 & $.585^{\star \star}$ \\
\hline \multirow{6}{*}{$\begin{array}{l}\text { Extraversion } \\
(\alpha=.61 ; \mathrm{CR}=.75 ; \mathrm{AVE}=.52)\end{array}$} & V13 & Serious & 3.47 & 1.18 & $.438^{\star \star}$ \\
\hline & V14 & Reserved & 3.19 & 1.20 & $.860^{\star \star}$ \\
\hline & V15 & Quiet $^{\mathrm{a}}$ & 3.38 & 1.18 & - \\
\hline & V16 & Retiring $^{\text {a }}$ & 3.90 & 1.04 & - \\
\hline & V17 & Unfeeling ${ }^{a}$ & 3.74 & .968 & - \\
\hline & V18 & Loner & 3.81 & 1.03 & $.613^{\star \star}$ \\
\hline
\end{tabular}




\begin{tabular}{|c|c|c|c|c|c|}
\hline \multicolumn{6}{|c|}{ Table 3: continuation } \\
\hline \multirow{6}{*}{$\begin{array}{l}\text { Openness } \\
(\alpha=.76 ; C R=.84 \\
A \vee=.52)\end{array}$} & V19 & Conventional & 3.46 & 1.06 & $.695^{\star \star}$ \\
\hline & V20 & Simple & 3.39 & 1.09 & $.539^{\star *}$ \\
\hline & V21 & Unadventurous $^{a}$ & - & - & - \\
\hline & V22 & Narrow interests & 3.40 & 1.12 & $.660^{\star \star}$ \\
\hline & V23 & Uncreative & 3.43 & 1.12 & $.859^{* *}$ \\
\hline & V24 & Down to earth & 3.09 & 1.18 & $.654^{* *}$ \\
\hline \multirow{6}{*}{$\begin{array}{l}\text { Agreeableness } \\
(\alpha=.64 ; \mathrm{CR}=.82 \\
\text { AVE }=.54)\end{array}$} & V25 & Ruthless & 3.48 & .985 & $.691^{\star *}$ \\
\hline & V26 & Suspicious & 3.23 & 1.16 & $.760^{\star *}$ \\
\hline & V27 & Callous & 3.88 & .969 & $.678^{\star *}$ \\
\hline & V28 & Antagonistic & 3.33 & .933 & $.590^{\star \star}$ \\
\hline & V29 & Critical $^{a}$ & 3.19 & 1.06 & - \\
\hline & V30 & Vengeful $^{a}$ & 3.07 & 1.07 & - \\
\hline \multirow{5}{*}{$\begin{array}{l}\text { Gaming self- } \\
\text { efficacy } \\
(\alpha=.78 ; \mathrm{CR}=.86 ; \\
\mathrm{AVE}=.61)\end{array}$} & V31 & I am very adept at handling game apps. & 3.28 & 1.27 & $.687^{* *}$ \\
\hline & V32 & $\begin{array}{l}\text { I find it very easy to get acquainted with the mechanics of } \\
\text { game apps }{ }^{c} \text {. }\end{array}$ & 3.75 & .969 & - \\
\hline & V33 & $\begin{array}{l}\text { I know how to solve most of the challenges that arise during } \\
\text { the game with apps. }\end{array}$ & 3.56 & 1.07 & $.855^{\star *}$ \\
\hline & V34 & $\begin{array}{l}\text { I know how to install new game apps, new applications, or } \\
\text { extensions of a video game with apps. }\end{array}$ & 3.86 & 1.15 & $.709^{* *}$ \\
\hline & V35 & I consider myself an expert gamer with apps. & 2.58 & 1.11 & $.726^{\star *}$ \\
\hline \multirow{5}{*}{$\begin{array}{l}\text { Online shopping } \\
\text { self-efficacy } \\
(\alpha=.91 ; \mathrm{CR}=.94 \\
\text { AVE=.75) }\end{array}$} & V36 & $\begin{array}{l}\text { I am very adept at searching for products and services on } \\
\text { the Internet. }\end{array}$ & 3.16 & 1.17 & $.885^{\star *}$ \\
\hline & V37 & $\begin{array}{l}\text { I find it very easy to get acquainted with several online } \\
\text { purchasing platforms. }\end{array}$ & 3.26 & 1.21 & $.904^{\star *}$ \\
\hline & V38 & $\begin{array}{l}\text { I know how to solve most of the problems that arise during } \\
\text { online purchases. }\end{array}$ & 2.96 & 1.22 & $.855^{\star *}$ \\
\hline & V39 & I know the best online stores where to purchase. & 3.15 & 1.21 & $.814^{\star *}$ \\
\hline & V40 & I consider myself an expert online buyer. & 2.47 & 1.22 & $.776^{\star *}$ \\
\hline \multirow{3}{*}{$\begin{array}{l}\text { Intention to } \\
\text { purchase online } \\
(\alpha=.73 ; \mathrm{CR}=.91 ; \\
\mathrm{AVE}=.61)\end{array}$} & V41 & $\begin{array}{l}\text { I intend to acquire virtual elements of this video game in my } \\
\text { future online purchases. }\end{array}$ & 1.29 & .759 & $.874^{* *}$ \\
\hline & V42 & $\begin{array}{l}\text { The probability of me buying online related elements of this } \\
\text { video game next time is high. }\end{array}$ & 1.25 & .676 & $.878^{\star *}$ \\
\hline & V43 & $\begin{array}{l}\text { I would be willing to accept advertising about related } \\
\text { products to purchase online again. }\end{array}$ & 1.66 & .991 & $.754^{\star *}$ \\
\hline \multirow{2}{*}{$\begin{array}{l}\text { Group norm } \\
\text { (marker variable) }\end{array}$} & V44 & $\begin{array}{l}\text { My group of players considers that our objective } \\
\text { (challenge) is to continue playing this game during the } \\
\text { coming days or weeks. }\end{array}$ & 3.11 & 1.34 & $.574^{* *}$ \\
\hline & V45 & $\begin{array}{l}\text { I will continue to play this video game with my group in the } \\
\text { next few days or weeks. }\end{array}$ & 2.27 & 1.30 & $.946^{\star *}$ \\
\hline \multirow{2}{*}{$\begin{array}{l}\text { Frequency } \\
\text { (control variables) }\end{array}$} & V46 & Frequency of playing with apps. & 3.64 & 1.18 & n.a $a^{b}$ \\
\hline & V47 & Frequency of on-line purchasing. & 2.50 & 1.16 & n.a $a^{b}$ \\
\hline
\end{tabular}

Notation: ${ }^{a}$ Suppressed item, ${ }^{\mathrm{b}}$ mono-item, n.a. no applicable, SD: standard deviation $\alpha$ : Cronbach alpha, CR: composite reliability, AVE: average variance extracted.

Significance levels: ${ }^{* *} p<.01$

Common method bias may exist when measures use the same method (self-report, scale type) and might yield inflated correlations between constructs. As recommended by [63], our assessment used the correlations between the BigFive latent constructs, two self-efficacy constructs, intention to purchase, and the marker variable with a two-item measure of group norm (V44 and V45) to perform this analysis. The correlation between group norm and purchase intention was .47. Using [63] formula, the corrected values for the correlations between consciousness and group norm, we computed the Common Method Variance (CMV) adjusted correlations among the research constructs using the second lowest correlation $(r=.04)$ as a proxy for marker variable. Table 4 shows the correlations between constructs below the diagonal and the adjusted correlations above the diagonal. We also determined the statistical significance of the adjusted correlations. All the correlations that were significant before adjustment also remained significant after adjustment. In this sense, marker-variable analysis indicated that common method bias is unlikely to affect the findings of this study. 
Table 4: Results for Fornell-Larcker criterion to test discriminant validity and marker-variable analysis

\begin{tabular}{|c|c|c|c|c|c|c|c|c|}
\hline & (1) & 2) & (3) & (4) & (5) & (6) & $(7)$ & $(8)$ \\
\hline (1) Gaming self-efficacy & .78 & .04 & $-.24^{\star *}$ & $.21^{* *}$ & $.27^{\star \star}$ & .03 & $.51^{\star *}$ & $.38^{* *}$ \\
\hline (2) Conscientiousness & -.01 & 74 & -.06 & $.26^{* *}$ & $.18^{\star *}$ & $.37^{* *}$ & -.01 & .04 \\
\hline (3) Neuroticism & $-.19^{* *}$ & .02 & .76 & .02 & $-.21^{* *}$ & -.04 & $-.18^{*}$ & $.31^{* *}$ \\
\hline (4) Extraversion & $.24^{* *}$ & 29 ** & .04 & .72 & $.71^{* *}$ & $.70^{* *}$ & $.18^{\star *}$ & .08 \\
\hline (5) Openness & $.30^{* *}$ & $21^{* *}$ & $-.17^{* \star}$ & $.70^{* *}$ & .72 & $.54^{* *}$ & $.27^{\star \star}$ & $.12^{*}$ \\
\hline (6) Agreeableness & .06 & 39 ** & .01 & $.71^{\star *}$ & $.57^{\star *}$ & .74 & .01 & .03 \\
\hline (7) Online shopping self-efficacy & $.53^{\star \star}$ & 03 & $-.14^{\star}$ & $.21^{* *}$ & $.28^{* *}$ & .05 & .87 & $.70^{* *}$ \\
\hline (8) Intention to purchase online & $.40^{* *}$ & 08 & $.33^{* *}$ & .11 & $.15^{*}$ & .06 & $.71^{* *}$ & .78 \\
\hline (9) Group norm & $.37^{\star *}$ & 00 & -.09 & $.13^{*}$ & $.14^{*}$ & .04 & $.28^{* *}$ & $.47^{* *}$ \\
\hline
\end{tabular}

Significance levels: ${ }^{* *} \mathrm{p}<.01,{ }^{*} \mathrm{p}<.05$

Note: values below the diagonal represent correlations between constructs, values on the diagonal (in bold) represent the square root of AVE and values above the diagonal represent the correlations between constructs adjusted for the marker variable (group norm).

The following step in the analysis was to test the proposed hypotheses using structural equation model (SEM) analysis (Figure 2).

Figure 2 reflects the proposed the results of the structural equation model estimation.

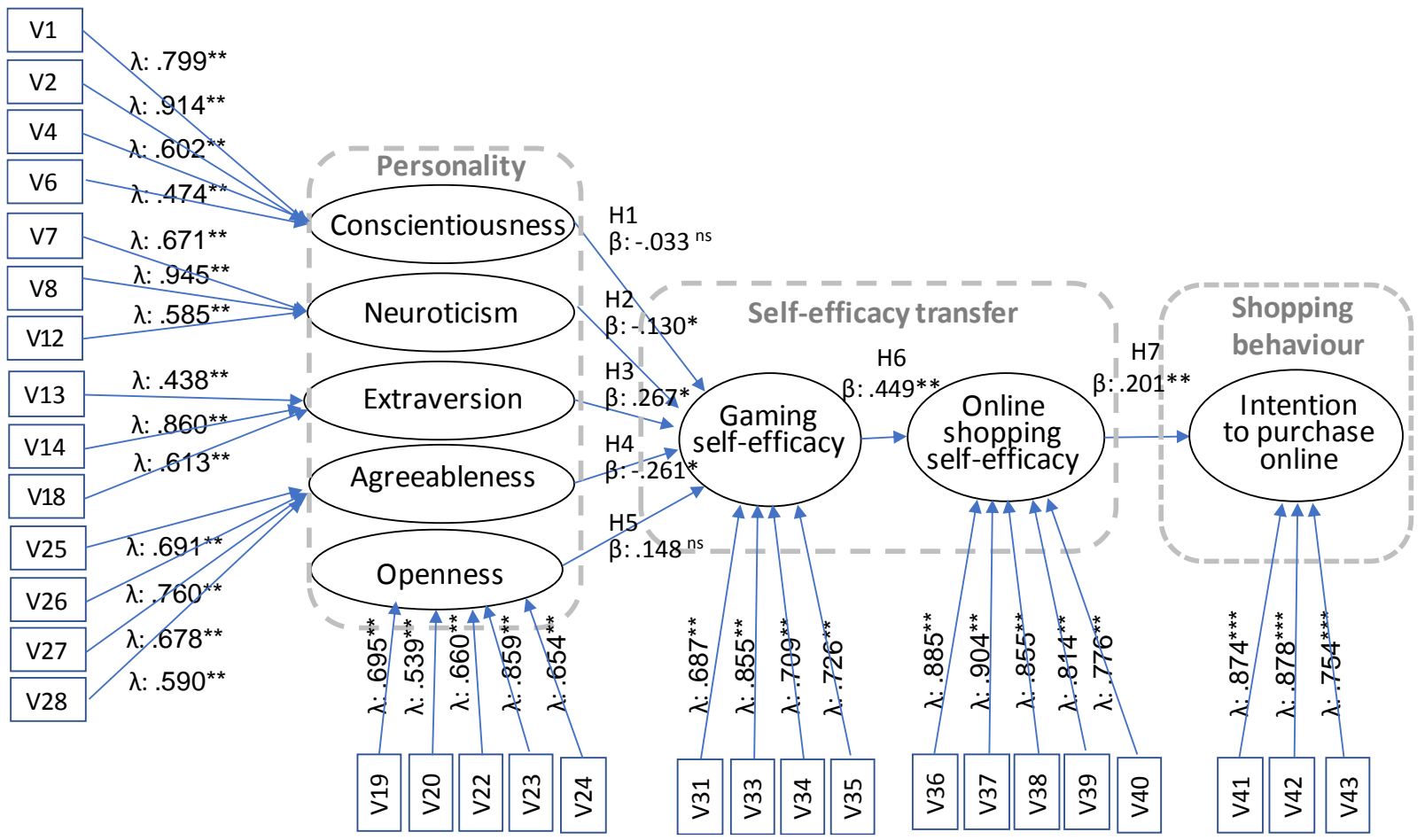

Figure 2: Model results

Significance levels: ${ }^{* *} \mathrm{p}<.01,{ }^{*} \mathrm{p}<.05$

All the hypotheses are supported at a confidence level of $95 \%$ except $\mathrm{H} 1$ and $\mathrm{H} 5$, which are rejected. Following prior research on self-efficacy [2], in order to ensure the validity of our results two gamers' behavioral variables (frequency of gaming with apps and frequency of online purchasing) were included in the model as control variables. Attending [19] recommendation, control variables must hold theoretically meaningful relationships with predictors and criteria. In this sense, prior research suggests that usage and purchase should be employed as dependent variables and relate to the frequency of this purchasing and gaming behavior [37]. Specifically, [2] support a bidirectional association between frequency of playing video games, self-reported problem-solving skills and gamers' behaviors (that may 
include online shopping related products and services). However, after controlling for these playing-related variables, no changes either in the significance or direction in the proposed relationships were detected. Table 5 presents the assessment of the overall model fit and the hypotheses supported.

Table 5: Results of SEM estimation of the proposed model

\begin{tabular}{|c|c|c|}
\hline Proposed hypothesis test & $\begin{array}{l}\text { Standardized } \\
\text { coefficient }(\beta)\end{array}$ & Result \\
\hline H1: Conscientiousness $\rightarrow$ Gaming self-efficacy & $-.033^{\mathrm{ns}}$ & Rejected \\
\hline H2: Neuroticism $\rightarrow$ Gaming self-efficacy & $-.130^{\star}$ & Accepted (95\%) \\
\hline H3: Extraversion $\rightarrow$ Gaming self-efficacy & $.267^{*}$ & Accepted (95\%) \\
\hline H4: Agreeableness $\rightarrow$ Gaming self-efficacy & $-.261^{*}$ & Accepted (95\%) \\
\hline H5: Openness $\rightarrow$ Gaming self-efficacy & $.148^{\mathrm{ns}}$ & Rejected \\
\hline H6: Gaming self-efficacy $\rightarrow$ Online shopping self-efficacy & $.449^{\star \star}$ & Accepted (99\%) \\
\hline H7: Online shopping self-efficacy $\rightarrow$ Intention to purchase online & $.201^{* *}$ & Accepted (99\%) \\
\hline \multicolumn{3}{|l|}{ Control variables } \\
\hline Frequency of playing with apps $\rightarrow$ Intention to purchase online & $.118^{\star \star}$ & - \\
\hline Frequency of shopping online $\rightarrow$ Intention to purchase online & $.101^{*}$ & - \\
\hline
\end{tabular}

Significance levels: ${ }^{* *} \mathrm{p}<.01,{ }^{*} \mathrm{p}<.05$, ${ }^{\mathrm{ns}}$ non-significance

Notation: Beta coefficient ( $\beta$ ); chi-square statistic (X2), Root-Mean-Square-Error of Approximation (RMSEA), Comparative Fit Index (CFI), and Goodness-of-Fit Index (GFI).

In addition, the Baron and Kenny [15] approach was followed in order to test the mediation effect of shopping selfefficacy in the model. We created a model including direct as well as indirect paths [80]. In other words, this model included all the paths in our research model (Figure 1) as well as an additional direct path from gaming self-efficacy (independent variable) to purchase intention (dependent variable). To test the mediating role of shopping self-efficacy, the mediation analysis results show that gaming self-efficacy remains significantly related to purchase intention after controlling for the mediating variable (shopping self-efficacy) $[(B=.252 ; p<.05)]$, suggesting a partial mediation effect of online shopping self-efficacy.

\section{Discussion and Implications}

As [82] underline, the finding that specific personality traits significantly relate to gaming self-efficacy gives credibility to the notion that individuals may inherently apply the efficacy acquired when playing to performing other tasks related to their shopping habits in the virtual context. Extrovert gamers show high gaming self-efficacy. These results support previous literature which suggests that an extrovert individual can more easily handle work pressure such that they perceive better performance [66]. In contrast, affable gamers might lack persistence, which makes them perceive lower gaming self-efficacy. Affable people tend to avoid challenging either themselves or their established ideas [62], [82]. Affable gamers may not, therefore, display high self-efficacy and may thus seek to avoid interpersonal conflicts, preferring to cooperate with others rather than compete with them.

In a similar way, neurotic people evidence characteristics that easily result in fear, anger, loneliness and dissatisfaction with themselves. Therefore, neurotic gamers also perceive lower self-efficacy when playing game apps. This might be caused by these negative feelings which could be curtailing gamers' ability to deal with gaming problems or difficulties [55]. Openness does not significantly generate or enhance gaming self-efficacy. There is no consensus in previous literature regarding this relationship. In fact, some authors find support for a relationship between openness and selfefficacy [82] whilst others do not [55]. Moreover, and in agreement with [82], conscientiousness does not influence gaming self-efficacy. In this sense, traits such as dependability, achievement orientation, perseverance, deliberation, scrupulousness, and punctuality do not seem to be related with gaming self-efficacy. This might be because conscientiousness characteristics could prove more important in a relevant and high-involvement task such as organizing and executing courses through computers [82] or buying a house [77] than it is in leisure activities (such as gaming) or the use of social networks [20]. According to previous evidence found by [95], when the purpose is to analyze virtual consumption (such as game apps and related-gamming products), consumers are disposed to communicate their self-concept (including their personality) via the use of the products that convey desirable, and this fact facilitates consumers' purchasing behaviors' regarding products that have certain personal significance.

Finally, the evidence about the positive transfer of self-efficacy among similar technological tasks (i.e., gaming and purchase through the Internet) contributes to a better understanding of shopper behavior. It is an interesting finding since there is a gap in the literature regarding the impact of gaming on consumer behavior [27], [37]. As for gaming app use, game-related self-efficacy drives the electronic commerce of game-related products. This finding is unique and important since it supports a widely accepted belief about game effects on gamers' self-perception and purchase behavior [37]. In addition, this study offers evidence that confirms the existence of different kinds of specific self- 
efficacy [29], [43], [52], [57], also in a gaming context, rather than only a general self-efficacy perception. The proposed sequence reveals that gamer personality differences can influence self-efficacy in gaming and that this is transferred to another task (shopping) as gamers play.

These personality traits that influence gaming self-efficacy indirectly affect online shopping self-efficacy, thus showing a transfer of self-efficacy between different technological tasks. Also, [91] found a partial mediating effect of selfefficacy between personality traits and behavioral intentions. In this way, the study confirms previous findings concerning the influence of specific kinds of self-efficacy on online shopping intentions [43], [45].

\subsection{Managerial Implications}

From a managerial perspective, understanding the phenomenon of self-efficacy transfer is crucial, as media such as game apps are beginning to play a major role in marketing activities. Companies are recognizing the potential of game apps as a means of marketing products and services. In agreement with [86] and the Theory of Innovation Diffusion, the popularity of video games makes them spread through social networks, motivating players through innovative and unique designs. Since, actual digital media users' philosophy of open access implies no immediate payment in order to play video game [44], game developers ought to be aware of the alternative paths (such as micropayments or virtual assets transactions) to reach gamers' purchase intention (in order to maintain the ecosystem developed for generating revenues).

Our results reveal how gaming might have practical implications for marketing managers. If firms teach players how to play, it could indirectly promote the online purchase of related products, which also supports the effectiveness of gamification strategies. In this sense, [53] propose the use of gamification strategies to offer a good video game, with added value, thus enhancing the playing experience and entailing benefits for both game developers and players alike. Keeping in mind that central to the game model is consumer choice, players will accept better non-imposed marketing strategies. In this sense, game developers may let master players (i.e., that show high gaming efficacy) to exchange information (tips, strategies or trick) for extra features with others, making easy microtransaction process between consumers (C2C commerce inside the game).

Managers should try to develop user-friendly and easy to surf sites so as to enhance convenience and allow users to become familiar with interfaces and show self-efficacy with Internet behaviors. In [43], the aspect of equivalent skill level as analogous to Rogers' evaluation criteria of perceived complexity is studied, which predicts faster adoption when technology is easier to use. A practical guideline for gaming companies is to employ social networks to connect with their customers to ask for feedback about the perceived level of online tasks difficulty and self-efficacy perception (about gaming and purchasing).

This research denotes possibilities for interventions by consumer educators and managerial video game industry actors. For example, platforms that offer a sense of comfort and an appealing task-accomplishment orientation helps to promote self-efficacy among users [45], [94]. To that end, providing flexible learning environments, also among members of a group who play games [100], can also be useful to promote user self-efficacy and help them achieve their goals successfully. Regard this result, game firms might reward players with free items (such as new level trials in advance, outfits or skipping stages) in return for sharing their knowledge with other gamers, if they are coaching other players, they are promoting and recommending [11], [93] to consume certain games and, finally enlarging the life cycle of the games and related products.

Finally, consumers who register high emotional stability and extraversion and low agreeableness are the target audience for firms operating in the video game industry as these are the personality traits that most influence selfefficacy and, consequently, the opportunities to acquire new abilities and transfer them to online buying behavior of game-related products. As app developers employ various business models to generate income, such as pay to play games, in-app purchases during play, or in-app advertising [40], gaming companies might be able to incentive gamers with a free trial period, free virtual elements or ad-free period experience in exchange for the information regarding gamers' personality and perceived self-efficacy to segment their market.

\section{Conclusion}

In an age of intense competition such as the present, any marketing action must commence with a good knowledge of which factors impact on client (player) behavior, whose actions can be explained by personal variables and interaction processes (in this case, consumption of game apps and related online purchasing). "Converting online mobile game users' to loyal customers is a mandatory action to instil purchase intention among them" [11] p. 244. The objectives of this study were: a) to consider game player personality as a driver of gamer self-efficacy; b) to study the transfer of self-efficacy from an app gaming context to an online shopping context; $c$ ) to explore the role of self-efficacy as an antecedent of the intention to purchase game-related products online. Although there are several studies on innovation adoption [36], [61] and only a few in the case of video game adoption [97], to the best of our knowledge there are no works addressing our understanding of the self-efficacy transfer process between two technological contexts. We feel that it is imperative for both scholars and marketers alike to understand the internal factors underlying gamers' behavior and how such factors make consumers embrace the online purchase of game-related products. 
The paper's contributions are as follows. Firstly, the study offers new insights into self-efficacy transfer in processes related to the use of new technologies. Little is known in the literature about the factors affecting self-efficacy since most research focuses on the impact of self-efficacy on technology adoption or acceptance [36], [82]. In fact, dispositional factors, such as personality traits, have remained largely unexplored in marketing literature. Secondly, this work evaluates the transfer process from game player behavior to online shopping intention for game-related products. As far as we are aware, only the study of [57] refers to shopping self-efficacy. In particular, the analysis establishes the existence of a process of self-efficacy transfer that ultimately leads to online purchase intention, a sequence of personality-self-efficacy-behavior which has relevant academic as well as managerial implications. Thirdly, the study focuses on a fast-growing industry, the game app industry and uses information collected from a wide sample of actual app gamers.

The results of this study show that there is only one personality trait -extraversion- which increases the perceived gaming self-efficacy while two personality traits -neuroticism and agreeableness- can reduce the perceived gaming self-efficacy. Likewise, it is remarkable that the results here imply a sequence of positive effects from gaming selfefficacy across online shopping self-efficacy until intention to purchase online. Therefore, the main managerial implication deriving from this work refers to the need for the firms to know the gamers' personality and segment the market accordingly as it affects their self-efficacy not only playing, but also shopping online.

\subsection{Limitations and Further Research}

The results are valid for Spain and for the video game industry and cannot, therefore, be generalized unambiguously. The sample is composed of game app players, who display a certain level of gaming self-efficacy. It would thus be advisable to study the moderating role of playing experience and the online purchase experience. Furthermore, we use a short version of the Big-Five inventory. Future studies should use another measurement instrument such as the 60 -item NEO five-factor inventory [33] and should go further about how could vary gamer's consumption behavior when playing different games apps at the same time. Other related factors such as the ease of use and purchase within each game [37] could be considered as being also of interest for marketers.

It might also prove enlightening to study the negative aspects of playing and online purchasing, such as perceived risk, social isolation or addiction, which leads to the interesting issue of self-regulation [35], [51]. It would be prudent to compare real-world activities and virtual worlds so as to ascertain whether adopting certain activities such as game app playing is a substitute for the real-world counterpart, as [43] suggests doing. In the same line, it would be interesting to compare the behavior of gamers and non-gamers [51] as well as to consider other antecedents of self-efficacy, such as emotional intelligence [91]. More research could be conducted for specific games, as there can even be a selfefficacy specific to a certain game. Finally, different genres of game apps might spark a different degree of self-efficacy transfer and personality trait influence.

\section{Acknowledgments}

The authors would like to thank the support provided by the Ministry of Economy and Competitiveness (ECO201782107-R) and the European Regional Development Fund (ERDF) and Junta de Castilla y León (Spain) (VA112P17).

\section{References}

[1] B. L. Abarbanel, Mapping the online gambling e-servicescape: A conceptual model, UNLV Gaming Research \& Review Journal, vol. 17, no. 2, pp. 27-44, 2013.

[2] P. JC, Adachi and T. Willoughby, More than just fun and games: The longitudinal relationships between strategic video games, self-reported problem solving skills, and academic grades, Journal of Youth and Adolescence, vol. 42, no. 7, pp. 1041-1052, 2013.

[3] AEVI. (2017) Anuario de la industria del videojuego. AEVI. [Online]. Available: http://www.aevi.org.es/web/wpcontent/uploads/2018/07/AEVI Anuario2017.pdf

[4] AEVI. (2015) Estudio videojuegos y adultos. [Online]. Available: http://www.aevi.org.es/web/wpcontent/uploads/2015/12/Estudio-Videojuegos-y-adultos presentaci\%Cl\%B3n.pdf

[5] J. C. Anderson and D. W. Gerbing, Structural equation modeling in practice: A review and recommended twostep approach, Psychological bulletin, vol. 103, no. 3, pp. 411-423, 1988.

[6] C. Andreassen, G. D. Mark, G. Siri, K. Elfrid, K. Siri, and S. Pallesen, The relationships between behavioral addictions and the five-factor model of personality, Journal of Behavioral Addictions, vol. 2, no. 2, pp. 90-99, 2013.

[7] J. Anglim and S.L. Grant, Incremental criterion prediction of personality facets over factors: Obtaining unbiased estimates and confidence intervals, Journal of Research in Personality, vol. 53, pp. 48-157, 2014.

[8] V. A. Badrinarayanan, J. J. Sierra and K. M. Martin, A dual identification framework of online multiplayer video games: The case of massively multiplayer online role playing games (MMORPGs), Journal of Business Research, vol. 68, no. 5, pp. 1045-1052, 2015.

[9] R. P. Bagozzi and Y. Yi, Specification, evaluation, and interpretation of structural equation models, Journal of the Academy of Marketing Science, vol. 40, no. 1, pp. 8-34, 2012. 
[10] A. Bandura, Self-efficacy: Toward a Unifying Theory of Behavioral Change, Psychological Review, vol. 84, no. 2 , pp.191-215, 1977.

[11] J. Balakrishnan and M. D. Griffiths, Loyalty towards online games, gaming addiction, and purchase intention towards online mobile in-game features, Computers in Human Behavior. Vol. 87, pp. 238-246, 2018.

[12] A. Bandura, Social Foundations of Thought and Action: A Social Cognitive Theory. Englewood Cliffs, NJ: PrenticeHall, 1986.

[13] A. Bandura, Self-efficacy: The Exercise of Control. New York: W H Freeman, 1997.

[14] A. Bandura, C. V. Gian, B. Claudio, G. Maria, and C. Pastorelli, Role of affective self-regulatory efficacy in diverse spheres of psychosocial dunctioning, Child Development, vol. 74, no. 3, pp. 769-782, 2003.

[15] R. M. Baron and D. A. Kenny, The moderator-mediator variable distinction in social psychological research: Conceptual, strategic, and statistical considerations, Journal of Personality and Social Psychology, vol. 51, no. 6, pp. 1173-1182, 1986.

[16] A. Bean and G. Groth-Marnat, Video gamers and personality: A five-factor model to understand game playing style, Psychology of Popular Media Culture, vol. 5, no. 1, pp. 27-38, 2016.

[17] T. Beauregard, Perfectionism, self-efficacy and OCB: The moderating role of gender, Personnel Review, vol. 41 , no. 5, pp. 590-608, 2012.

[18] J-F. Bélisle and H. O. Bodur, Avatars as information: Perception of consumers based on their avatars in virtual worlds, Psychology \& Marketing, vol. 27, no. 8, pp. 741-765, 2010.

[19] J. B. Bernerth and H. Aguinis. A critical review and best-practice recommendations for control variable usage, Personnel Psychology, vol. 69, no. 1, pp. 229-283, 2016.

[20] A. Błachnio, A. Przepiórka and P. Rudnicka, Psychological determinants of using Facebook: A research review, International Journal of Human-Computer Interaction, vol. 29, no. 11, pp. 775-787, 2013.

[21] M. Bong and D. Hocevar, Measuring self-efficacy: Multitrait-multimethod comparison of scaling procedures, Applied Measurement in Education, vol. 15, no. 2, pp. 143-171, 2002.

[22] P. Bouvier, E. Lavoué and K. Sehaba, Defining engagement and characterizing engaged-behaviors in digital gaming, Simulation \& Gaming, vol. 45, no. 4-5, pp. 491-507, 2014.

[23] J. M. Braun, K. W. Stopfer, M. E. Müller, and B. Egloff. Personality and video gaming: Comparing regular gamers, non-gamers, and gaming addicts and differentiating between game genres, Computers in Human Behavior, vol. 55, Part A, pp. 406-412, 2016.

[24] R. W. Brislin, Cross-cultural research methods, in Environment and Culture (I. Altman, A. Rapoport and J.F. Wohlwill, Eds.). New York: Springer, 1980, pp. 47-82.

[25] K. E. Buckley and C. A. Anderson, A theoretical model of the effects and consequences of playing video games, in Playing Video Games - Motives, Responses, and Consequences (P. Vorderer and J. Bryant, Eds.). Mahwah, New Jersey, US: Lawrence Erlbaum Associates Publishers, 2006, pp. 363-378.

[26] A. Chen, Y. Lu and B. Wang, Enhancing perceived enjoyment in social games through social and gaming factors, Information Technology \& People, vol. 29, no. 1, pp. 99-119, 2016.

[27] A. Chen and L. Leung, Are you addicted to candy crush saga? An exploratory study linking psychological factors to mobile social game addiction, Telematics and Informatics, vol. 33, no. 4, pp. 1155-1166, 2016.

[28] A. Chen, S. M. Gully and D. Eden. Validation of a new general self-efficacy scale, Organizational Research Methods, vol. 4, no. 1, pp. 62-83, 2001.

[29] K. Chen, J. V. Chen and D. C. Yen, Dimensions of self-efficacy in the study of smart phone acceptance, Computer Standards \& Interfaces, vol. 33, no. 4, pp. 422-431, 2011.

[30] L. S-L. Chen, H. H-J. Tu and E. Shih-Tse Wang, Personality traits and life satisfaction among online game players CyberPsychology \& Behavior, vol. 11, no. 2, pp. 145-149, 2008.

[31] E. Collins, J. Freeman and T. Chamarro-Premuzic, Personality traits associated with problematic and nonproblematic massively multiplayer online role-playing game use, Personality and Individual Differences, vol. 52 , no. 2, pp. 133-138, 2012.

[32] P. T. Costa and R. McCrae, The NEO Personality Inventory Manual. Florida: Odessa, Psychological Assessment Resources, 1985.

[33] P. T. Costa and R. McCrae, Revised NEO Personality Inventory (NEO-PI-R) and NEO Five-Factor Inventory (NEO-FFI) Professional Manual. Florida: Odessa, Psychological Assessment Resources, Inc, 1992.

[34] Clairfield International GmbH. (2018, January) Gaming industry - facts, figures and trends. Clairfield. [Online] Available: http://www.clairfield.com/wp-content/uploads/2017/02/Gaming-Industry-and-Market-Report-2018.012.pdf

[35] C. Dang, Dynamic user experience of information technology innovations: A self-regulatory perspective. Ph.D. dissertation, Michigan State University, Michigan, 2009.

[36] S. Dash and K. B. Saji, The role of consumer self-efficacy and website social-presence in customers' adoption of B2C online shopping, Journal of International Consumer Marketing, vol. 20, no. 2, pp. 33-48, 2008.

[37] R. Davis and B. Lang. Does game self-congruity increase usage and purchase? Young Consumers, vol. 14, no. 1, pp. 52-66, 2013.

[38] C. deGraft-Johnson, Y-C. Wang, M.B. Sutherland, and K. Norman. (2013, August) Relating five factor personality traits to video game preference. Human-Computer Interaction Technical Report. [Online]. Available: http://hcil2.cs.umd.edu/trs/2013-08/2013-08.pdf

[39] DEV-Spanish Association of Enterprises Producers and Developers of Video Games and Entertainment Software. (2017) Libro Blanco del Desarrollo Español de Videojuegos. DEV. [Online]. Available: www.dev.org.es 
[40] Deloitte. (2015) Mobile games in Europe Innovation in European Digital Economy. Deloitte. [Online]. Available: https://euipo.europa.eu/ohimportal/delegate/webcontent-services/admindocs/wsdocumentdl/VZIUDX OSFQUIJ5 OEO6HWWAPID2NVL7U276HVLNGG5TAW5S2Y3VPR253LWZXGPJ64CJQZWA27DVWD2.

[41] I. De Voldere, J-F. Romainville, S. Knotter, E. Durinck, E. Engin, A. Le Gall, P. Kern, E. Airaghi, T. Pletosu, H. Ranaivoson, and K. Hoelck. (2017) Mapping the creative value chains. A study on the economy of culture in the digital age. Keanet. [Online]. Available: http://www.keanet.eu/wp-content/uploads/Final-report-Creative-ValueChains.pdf

[42] J. B. Dinsmore, K. Swani and R. G. Dugan, To free or not to free: Trait predictors of mobile app purchasing tendencies, Psychology \& Marketing, vol. 34, no. 2, pp. 227-244, 2017.

[43] M. Eastin, Diffusion of e-commerce: An analysis of the adoption of four e-commerce activities, Telematics and Informatics, vol. 19, no. 3, pp. 251-267, 2002.

[44] E. Evans, The economics of free: Freemium games, branding and the impatience economy, Convergence: The International Journal of Research into New Media Technologies, vol. 22, no. 6, pp. 563-580, 2016.

[45] K. Faqih, An empirical analysis of factors predicting the behavioral intention to adopt Internet shopping technology among non-shoppers in a developing country context: Does gender matter? Journal of Retailing \& Consumer Services, vol. 30, pp. 140-164, 2016

[46] C. Fornell and D. F. Larcker, Evaluating structural equation models with unobservable variables and measurement error, Journal of Marketing Research, vol. 18, no. 1, pp. 39-50, 1981.

[47] D. George and P. Mallery, SPSS for Windows Step by Step: A Simple Guide and Reference. 11.0 Update. Boston: Allyn \& Bacon, 2003.

[48] S. D. Gosling, P. J. Rentfrow and W. B. Swann, A very brief measure of the big-five personality domains, Journa of Research in Personality, vol. 37, no. 6, pp. 504-528, 2003.

[49] L. T. Graham and S. D. Gosling, Personality profiles associated with different motivations for playing world of Warcraft, Cyberpsychology, Behavior, and Social Networking, vol. 16, no. 3, pp. 189-193, 2013.

[50] J. F. Hair, W. C. Black, B. J. Babin, and R. E. Anderson, Multivariate Data Analysis. United States: Pearson/Prentice Hall, 2010

[51] M. Harma, T. Aktan and K. Cagiltay, Aim, shoot, deplete: Playing video games depletes self-regulatory resources, International Journal of Human-Computer Interaction, vol. 31, no. 7, pp. 451-456, 2015.

[52] M-H. Hsu and C-M Chiu, Internet self-efficacy and electronic service acceptance, Decision Support Systems, vol. 38, no. 3, pp. 369-381, 2004.

[53] K. Huotari and J. Hamari, Defining gamification: a service marketing perspective, in Proceeding of the 16th International Academic MindTrek Conference, Tampere, Finland: ACM Press, 2012, pp. 17-22.

[54] ISFE. (2017) Gametrack digest: Quarter 3. ISFE. [Online]. Available: https://www.isfe.eu/sites/isfe.eu/files/ gametrack european summary data 2017 q3.pdf

[55] T. A. Judge, C. L. Jackson, J. C. Shaw, B. A. Scott, and B. L. Rich, Self-efficacy and work-welated performance: The integral role of individual differences, Journal of Applied Psychology, vol. 92, no. 1, pp. 107-127, 2007.

[56] A. Kazeminia, M. Kaedi and B. Ganji, Personality-based personalization of online store features using genetic programming: Analysis and experiment, Journal of Theoretical and Applied Electronic Commerce Research, vol. 14, no. 1, pp. 16-29, 2019.

[57] J. Ketelhut, Assessing gaming, computer and scientific inquiry self-efficacy in a virtual environment, in Serious Educational Game Assessment: Practical Methods and Models for Educational Games, Simulations and Virtual Worlds (L. Annetta and S.C. Bronack, Eds.). Philadelphia: Sense Publishers, 2011, pp. 1-18.

[58] H. Khang, J. Kim and Y. Kim. Self-traits and motivations as antecedents of digital media flow and addiction: The internet, mobile phones, and video games, Computers in Human Behavior, vol. 29, no. 6, pp. 2416-2424, 2013.

[59] M. Kiyici, Internet shopping behavior of college education students of Turkey's university, The Turkish Online Journal of Educational Technology, vol. 11, no. 3, pp. 202-214, 2012.

[60] R. Landers and J. W. Lounsbury, An investigation of big five and narrow personality traits in relation to internet usage, Computers in Human Behavior, vol. 22, no. 2, pp. 283-293, 2006.

[61] W. M. Lassar, C. Manolis and S. Lassar, The relationship between consumer innovativeness, personal characteristics, and online banking adoption, International Journal of Bank Marketing, vol. 23, no. 2, pp. 176-199, 2005.

[62] L-Y. Lin, The relationship of consumer personality trait, brand personality and brand loyalty: An empirical study of toys and video games buyers, Journal of Product \& Brand Management, vol. 19, no. 1, pp. 4-17, 2010.

[63] M. K. Lindell and D. J. Whitney, Accounting for common method variance in cross-sectional research designs, Journal of Applied Psychology, vol. 86, no. 1, pp. 114-121, 2001.

[64] L. Mallalieu and K. M. Palan, How good a shopper am I? Conceptualizing teenage girls' perceived shopping competence, Academy of Marketing Sciences Review, vol. 5, pp. 1-28, 2006.

[65] A. Marchand and T. Hennig-Thurau, Value creation in the video game industry: Industry economics, consumer benefits, and research opportunities, Journal of Interactive Marketing, vol. 27, no. 3, pp. 141-157, 2013.

[66] K. Matzler, S. Bidmon and S. Grabner-Kräuter, Individual determinants of brand affect: the role of the personality traits of extraversion and openness to experience, Journal of Product \& Brand Management, vol. 15, no. 7, pp. 427-434, 2006

[67] R. R. McCrae and P. T. Costa, A five-factor theory of personality, in Handbook of Personality: Theory and Research (L.A. Pervin and O.P. John, Eds.). New York, NY: Guilford Press, 1999, pp. 139-153.

[68] R. R. McCrae, P. T. Costa and C. M. Busch, Evaluating comprehensiveness in personality systems: The California q-set and the five-factor model, Journal of Personality, vol. 54, no. 2, pp. 430-446, 2006. 
[69] M. Mehroof and M. D. Griffiths, Online gaming addiction: the role of sensation seeking, self-control, neuroticism, aggression, state anxiety, and trait anxiety, Cyberpsychology, Behavior, and Social Networking, vol. 13, no. 3, pp. 313-316, 2010

[70] R. G. Netemeyer, W. O. Bearden and S. Sharma, Scaling procedures: Issues and applications. California: Sage Publications, 2003.

[71] Newzoo. (2018) Global games market report. Newzoo. [Online]. Available: https://newzoo.com/insights/markets/ games/

[72] TERA. (2014, October) The economic contribution of the creative industries to EU GDP and employment. TERA [Online]. Available: http://www.teraconsultants.fr/en/issues/The-Economic-Contribution-of-the-Creative-Indus tries-to-EU-in-GDP-and-Employment

[73] T. T. Nguyen, F. M. Harper, L. Terveen, and J. A. Konstan, User personality and user satisfaction with recommender systems, Information Systems Frontiers, vol. 20, no. 6, pp. 1173-1189, 2018

[74] ONTSI. (2018) Informe anual del sector de los contenidos digitales en España. Ontsi. [Online]. Available: https://www.ontsi.red.es/ontsi/sites/ontsi/files/InformeSectorContenidosDigitales2018 0.pdf

[75] ONTSI. (2018) eComm 2015, edicion 2017 (Diario de Compras y Logística). Ontsi. [Online]. Available: https://www.ontsi.red.es/ontsi/sites/ontsi/files/Estudio\%20sobre\%20Comercio\%20Electr\%C3\%B3nico\%20B2C \%202017\%20\%28edici\%C3\%B3n\%202018\%29\%20 0.pdf

[76] J. Park, Y. Song and C-I. Teng, Exploring the links between personality traits and motivations to play online games, Cyberpsychology, Behavior, and Social Networking, vol. 14, no. 12, pp. 747-751, 2011.

[77] Y. Peng, H-H. Hsiung and K-H. Chen, The level of concern about Feng Shui in house purchasing: The impacts of self-efficacy, Superstition, and the Big Five Personality Traits. Psychology \& Marketing, vol. 29, no. 7, pp. 519530, 2012.

[78] R. A. Peterson and Y. Kim, On the relationship between coefficient alpha and composite reliability, Journal of Applied Psychology, vol. 98, no. 1, pp. 194-198, 2013.

[79] M. Rogers, Diffusion of Innovations. Nueva York: Ed. Free Press, 2003.

[80] D. Rucker, K. J. Preacher, Z. L. Tormala, and R. E. Petty. Mediation analysis in social psychology: Current practices and new recommendations, Social and Personality Psychology Compass, vol. 5, no. 6, pp. 359-371, 2011

[81] T. Ryan and S. Xenos, Who uses Facebook? An investigation into the relationship between the big five, shyness, narcissism, loneliness, and Facebook usage, Computers in Human Behavior, vol. 27, no. 5, pp. 1658-1664, 2011.

[82] H. Saleem, A. Beaudry and A-M. Croteau, Antecedents of computer self-efficacy: A study of the role of personality traits and gender, Computers in Human Behavior, vol. 27, no. 5, pp. 1922-1936, 2011.

[83] J. Sandy, S. D. Gosling and J. Durant, Predicting consumer behavior and media preferences: The comparative validity of personality traits and demographic variables, Psychology \& Marketing, vol. 30, no. 11, pp. 937-949, 2013

[84] L. Schjoedt and J. B. Craig, Development and validation of a unidimensional domain-specific entrepreneurial selfefficacy scale, International Journal of Entrepreneurial Behavior \& Research, vol. 23, no. 1, pp. 98-113, 2017.

[85] S. Seok and B. DaCosta, Predicting video game behavior: an investigation of the relationship between personality and mobile game play, Games and Culture, vol. 10, no. 5, pp. 481-501, 2015.

[86] K-S. Shen, Measuring the sociocultural appeal of SNS games in Taiwan, Internet Research, vol. 23, no. 3, pp. 372-392, 2013

[87] Statista 2019. Number of smartphone users worldwide from 2014 to 2020 (in billions) [Online]. Available: https://www.statista.com/statistics/330695/number-of-smartphone-users-worldwide/ [Accessed January 2019].

[88] Statista. (2019, March) Video game monetization - statistics \& facts. Statista. [Online]. Available: https://www.statista.com/topics/3436/gaming-monetization/

[89] Satista. (2019) Mobile gaming app revenue worldwide in 2015, 2016 and 2020 (in billion U.S. dollars). Statista [Online]. Available: https://www.statista.com/statistics/511639/global-mobile-game-app-revenue/

[90] C-I. Teng, Personality differences between online game players and nonplayers in a student sample, CyberPsychology \& Behavior, vol. 11, no. 2, pp. 232-234, 2008.

[91] Y. Tsarenko and Y. Strizhakova, Coping with service failures: The role of emotional intelligence, self-efficacy and intention to complain, European Journal of Marketing, vol. 47, no. 1/2, pp. 71-92, 2013

[92] J. A. Velez and Mi. D. Hanus, Self-affirmation theory and performance feedback: When scoring high makes you feel low, Cyberpsychology, Behavior, and Social Networking, vol. 19, no. 12, pp. 721-726, 2016.

[93] P. Xu, L. Chen and R. Santhanam, Will video be the next generation of e-commerce product reviews? Presentation format and the role of product type, Decision Support Systems, vol. 73, pp. 85-96, 2015

[94] D. Walker, R. N. Laczniak, L. Carlson, and E. D. Brocato, Parenting orientations as antecedents of children's violent videogame play, Journal of Consumer Affairs, vol. 50, no. 2, pp. 430-457, 2016.

[95] W-T. Wang and W-H Chang, A study of virtual product consumption from the expectancy disconfirmation and symbolic consumption perspectives, Information Systems Frontiers, vol. 16, no. 5, pp. 887-908, 2014

[96] T. Wittek, T. R. Finserås, S. Pallesen, R. A. Mentzoni, D. Hanss, M. D. Griffiths, and H. Molde, Prevalence and predictors of video game addiction: A study based on a national representative sample of gamers, International Journal of Mental Health and Addiction, vol. 14, no. 5, pp. 672-686, 2016.

[97] N. C. Worth and A. S. Book, Personality and behavior in a massively multiplayer online role-playing game, Computers in Human Behavior, vol. 38, pp. 322-330, 2014.

[98] C-C. Wu, Chi-Cheng, Y-J. Chen, and Y-J. Cho, Nested network effects in online free games with accessory Selling, Journal of Interactive Marketing, vol. 27, no. 3, pp. 158-171, 2013. 
[99] T-H. Wu, S-M. Huang, S. Y. Huang, and D. C. Yen, The effect of competencies, team problem-solving ability, and computer audit activity on internal audit performance, Information Systems Frontiers, vol. 19, no. 5, pp. 11331148, 2017.

[100] A. Yam, R. Russell-Bennett, M. Foth, and R. Mulcahy, How does serious m-game technology encourage lowincome households to perform socially responsible behaviors? Psychology \& Marketing, vol. 34, no. 4, pp. 394409, 2017.

[101] E. Zetou, N. Vernadakis, V. Derri, E. Bebetsos, and F. Filippou, The effect of game for understanding on backhand tennis skill learning and self-efficacy improvement in elementary students, Procedia - Social and Behavioral Sciences, vol. 152, pp. 765-771, 2014. 